\title{
In Vivo Antimalarial Test of Artocarpin and in vitro Antimalarial Test of Artonin M Isolated from Artocarpus
}

\author{
TATI SUHARTATI ${ }^{1, *}$, EKA EPRIYANTI ${ }^{1}$, INGGIT BORISHA ${ }^{1}$, YANDRI ${ }^{1}$, \\ JHONS F. SUWANDI ${ }^{2}$, SURIPTO D. YUWONO ${ }^{1}$, HARDOKO I. QUDUS ${ }^{1}$, SUTOPO HADI ${ }^{1}$ \\ ${ }^{1}$ Department of Chemistry, Faculty of Mathematics and Natural Sciences, Universitas Lampung, Bandar Lampung 35145, \\ Indonesia \\ ${ }^{2}$ Faculty of Medicine, Universitas Lampung, Bandar Lampung 35145, Indonesia
}

\begin{abstract}
The derivative of flavonoid compounds, artocarpin (1) and artonin $M(2)$, were isolated from the root wood of Artocarpus altilis and from the root bark of A. kemando, respectively. Both plants originated from Lampung, Indonesia. The structure of the two compounds has been carefully determined by physical method and spectroscopy techniques of $U V, I R$, and NMR. The in vivo antimalarial test of artocarpin showed very good Plasmodium activity in female mice, with ED 50 value of $34.88 \mathrm{mg} / \mathrm{kg}$ body weight $(\mathrm{kgBW})$, whereas the in vitro antimalarial test of artonin $M$ showed very strong activity with $\mathrm{IC}_{50}$ of $0.3 \mathrm{\mu g} / \mathrm{mL}\left(5.967 \times 10^{-7} \mathrm{M}\right)$.
\end{abstract}

Keywords: antimalarial, artocarpin, artonin M, A. altilis, A. kemando

\section{Introduction}

The antimalarial researches on flavanoid compounds isolated from artocarpus plants have been carried out and reported previously [1-4]. The compounds isolated from these plants were very interesting to explore as an antimalarial drug. Artonin E, cycloartobiloxanthone, artocarpin, cycloartocarpin isolated from $A$. altilis have been found to exhibit cytotoxic activity against Plasmodium falciparum. All of these active compounds are prenylated on $\mathrm{C} 3$, and the antimalarial activity test previously performed on these compounds were usually in vitro activity test [1-4].

A. kemando Miq. is one of endemic plants that grows in Indonesia. From this plant, some prenylated flavanoids have been isolated, and these include artomandin, artoindonesianin $\mathrm{C}$, artonol B, and artochamin A [5]. All of these compounds have been found to show cytotoxic activity against KB cell cancer (human oral epidermoid carcinoma); thus, this plant is known as a source of promising anticancer drug [6]. Futhermore, artonin E, artonin O, artobiloxanthone, and cylcoartobiloxanthone have also been found active as anticancer [5-7]. However, the antimalarial activity test of the compounds isolated from $A$. kemando is not available yet.

The previous results of in vitro antimalarial activity test from flavanoid compounds obtained from Artocarpus indicated that many flavanoids were active and considered as antimalaria [1-4], but no reports have been found for the in vivo antimalarial test. Thus, in this paper, we reported the in vivo antimalarial test of artocarpin isolated from A. altilis and in vitro antimalarial activity of artonin $\mathrm{M}$ isolated from A. kemando Miq.

\section{Materials and methods}

\subsection{Plant materials}

The root woods of A. altilis were collected from Banjar Negara village, Tanggamus, Lampung, and the root bark of the Pudau plant (Artocarpus kemando Miq.) was obtained from Karang Anyar Hamlet, Klaten Village, Penengahan District, South Lampung Regency, Lampung Province, Indonesia. They were identified at Herbarium Bogoriense, Research Center for Biology, Indonesian Institute of Sciences, Bogor, Indonesia, and a voucher specimen of each plant has been deposited at the herbarium.

*email: tati.suhartati@fmipa.unila.ac.id 


\subsection{General Experimental Procedures}

Thin layer chromatography (TLC) analysis was carried out on pre-coated Si-gel plates (Merck Kieselgel 60 F254), and the UV lamp of Spectroline, ENF-240 C/F model was used to see the spot in TLC. VLC was carried out using Merck Si-gel 60. Melting points were determined on a Fisher Jhons micro-melting point apparatus and were uncorrected. UV-Vis and IR spectra were measured with Beckman DU-7000 and Varian 2000 FTIR spectrophotometers, respectively. ${ }^{1} \mathrm{H}-\mathrm{NMR}$ spectrum was recorded with a JEOL ECA 500 spectrometer, operating at $500.00 \mathrm{MHz}$ and ${ }^{13} \mathrm{C}-\mathrm{NMR}$ operating at $125 \mathrm{MHz}$.

\subsection{Isolation and Purification of the Compounds}

$2.6 \mathrm{~kg}$ of root wood A. altilis was mashed and was macerated using $16 \mathrm{~L}$ of methanol solvent, for $3 \times 24$ hours. The maceration results were then filtered and concentrated, obtained 83.46 grams of the extract. The maceration extract was fractionated using Vacuum Liquid Chromatography (VLC), received 2 stages of VLC using Merck 60 Silica Gel adsorbent (35-70 Mesh) and amylose, and eluted with a mixture of ethyl acetate $/ n$-hexane which gradually increased its polarity. Fractionation results produced 4 main fractions (A-D), fraction B $0.9 \mathrm{~g}, \mathrm{C} 1.93 \mathrm{~g}$, and D $13.8 \mathrm{~g}$.

The fractions $\mathrm{B}$ and $\mathrm{C}$ were VLC and subsequently in $\mathrm{CC}$ repeatedly using the same adsorbent and eluent, compound (1), as much as 0.63 grams, and exhibited melting point $185^{\circ} \mathrm{C}-186.8^{\circ} \mathrm{C}$. TLC with an artocarpine standard using three systems of ethyl acetate / $n$-hexane eluent 2: 8 (Rf 0.14), acetone / dichloromethane 1: 9 ( Rf 0.51), and acetone / n-hexane 3: 7 (Rf 0.37), and one stain was obtained with the same Rf.

$2.0 \mathrm{~kg}$ fine powder of root bark was macerated with a methanol solvent for $1 \times 24$ hours with three repetitions. The results of maceration were evaporated using a rotary evaporator and obtained 149.8 grams of extract. The extract obtained was then fractionated by the VLC method, with adsorbent silica gel and eluent $n$-hexane and ethyl acetate with variations in polarity increase. The results of the fractionation obtained seven main fractions, A - G. Fraction C received 16.7 grams in VLC further with the same adsorbent and eluent, and after that, the column chromatography was repeated using silica gel adsorbents and variations in n-hexane and ethyl eluents. Acetate and n-hexane and acetone obtained yellow crystals (compound 2) weighing $8.8 \mathrm{mg}$, with a melting point $248-251{ }^{\circ} \mathrm{C}$. In TLC compounds (2) with 3 eluent systems, namely n-hexane: acetone: dichloromethane (DCM) (2: 1: 1) (c), acetone: n-hexane (3: 7) (b), EtOAc: $\mathrm{n}$-hexane (2: 8), one stain was obtained.

Artocarpin (1) (Figure 1): yellow needle crystal, melting point $185^{\circ} \mathrm{C}-186.8^{\circ} \mathrm{C}$; UV-Vis $\lambda_{\max }$. $(\mathrm{MeOH}), \mathrm{nm}(\log \varepsilon): 279$ (4.56) and $324(4,11) ; \lambda_{\max }(\mathrm{MeOH}+\mathrm{NaOH}): 278$ and 362 ; the $\lambda_{\text {max. }}$ change was not observed in $\mathrm{MeOH}+\mathrm{AlCl}_{3}$ or in $\mathrm{MeOH}+\mathrm{NaOAc}$. IR $v_{\max }(\mathrm{KBr}) \mathrm{cm}^{-1}: 3392,3380,2960$, 2930, 1647, 1620, 1483, 1451, 1362, 1207, 1153, 1099, 978, 850, and 809. ${ }^{1} \mathrm{H}-\mathrm{NMR}$ (in acetone- $\mathrm{D}_{6}$, $500 \mathrm{MHz}) \delta(\mathrm{ppm}): 6.56(1 \mathrm{H}, \mathrm{s}, \mathrm{H}-8), 3.12(2 \mathrm{H}, \mathrm{d}, J=7.1 \mathrm{~Hz}, \mathrm{H}-9) ; 5.12(1 \mathrm{H}, \mathrm{m}, \mathrm{H}-10) ; 1.43$ (3H, s, $\mathrm{H}-12), 1.57(3 \mathrm{H}, \mathrm{d}, J=1.3 \mathrm{~Hz}, \mathrm{H}=13), 6.6(1 \mathrm{H}, \mathrm{d}, J=16.2 \mathrm{~Hz}, \mathrm{H}-14), 6.7(1 \mathrm{H}, \mathrm{dd}, J=7.1$ and 17.2 $\mathrm{Hz}, \mathrm{H}-15), 2.41(1 \mathrm{H}, \mathrm{m}, \mathrm{H}-16), 1.07(6 \mathrm{H}, \mathrm{d}, J=6.5 \mathrm{~Hz}, \mathrm{H}-17$ and 18$), 7.2(1 \mathrm{H}, \mathrm{d}, J=8.45 \mathrm{~Hz}, \mathrm{H}-6$ '), $6.51\left(1 \mathrm{H}, \mathrm{dd}, J=2\right.$ and $8.4 \mathrm{~Hz}, \mathrm{H}-5$ ') $6.57\left(1 \mathrm{H}, \mathrm{d}, J=2 \mathrm{~Hz}, \mathrm{H}-3\right.$ '), $3.96\left(3 \mathrm{H},-\mathrm{OCH}_{3}, \mathrm{~s}\right) .{ }^{13} \mathrm{C}-\mathrm{NMR}$ (in acetone-D6, $125 \mathrm{MHz}): \delta(\mathrm{ppm}): 163.9$ (C-2), 122.0 (C-3), 183.4 (C-4), 105.6(C-4a), 159.9 (C-5), 109.8 (C-6), 163.9 (C-7), 90.7 (C-8), 159.9 (C-8a), 112.9 (C-1'), 157.5 (C-2'), 103.8 (C-3'), 161.6 (C4'), 108.1 (C-5'), 132.4 (C-6'), 24.7 (C-9), 122.6 (C-10), 132.2 (C-11), 25.9 (C-12), 17.7 (C-13), 117.1 (C-14), 142.3 (C-15), 34.1 (C-16), 23.2 (C-17 and $\mathrm{C}-18)$, and $56.7\left(-\mathrm{OCH}_{3}\right)$. The ${ }^{1} \mathrm{H}$ and ${ }^{13} \mathrm{C}$ NMR spectra of this compound are shown in Figures 2 and 3, while the HMQC and HMBC spectra of $\mathbf{1}$ is in Figures 4 and 5, and the important correlation of $\mathbf{1}$ is in Figure 6.

Artonin M (2) (Figure 1): yellow needle crystal, melting point $248-251^{\circ} \mathrm{C}$. UV-Vis $\lambda_{\max }(\mathrm{MeOH})$ $\mathrm{nm}(\log \varepsilon): 203$ (4,66, H); $290(4,48) ; 348(4,19)$; and $385(4,27) ; \lambda_{\max }(\mathrm{MeOH}+\mathrm{NaOH}): 212,266$, 388 , and 467. IR $v_{\max }(\mathrm{KBr}) \mathrm{cm}^{-1}: 3568,3427,2974,2924,1653,1598,1550,1473,1355,1271$, and 1151. ${ }^{1} \mathrm{H}-\mathrm{NMR}$ (in methanol-D4, $\left.\mathrm{CD}_{3} \mathrm{OD}, 500 \mathrm{MHz}\right) \delta(\mathrm{ppm}): 1.31(3 \mathrm{H}, \mathrm{s}, \mathrm{H}-12) ; 1.45(6 \mathrm{H}, \mathrm{s}, \mathrm{H}-22$ 
and $\mathrm{H}-23) ; 1.67$ (3H, d, $J=1.2 \mathrm{~Hz}, \mathrm{H}-17) ; 1.70(3 \mathrm{H}, \mathrm{d}, J=1.4 \mathrm{~Hz}, \mathrm{H}-18) ; 1.95$ (2H, m, H-14); 2.2 $(2 \mathrm{H}, \mathrm{m}, \mathrm{H}-13) ; 2.40(1 \mathrm{H}, \mathrm{t}, J=15.2 \mathrm{~Hz}, \mathrm{H}-9), 3.10(1 \mathrm{H}, \mathrm{dd}, J=7$ and $15.1 \mathrm{~Hz}, \mathrm{H}-9) ; 3.41(1 \mathrm{H}, \mathrm{dd}, J=$ 7 and $15.2 \mathrm{~Hz}, \mathrm{H}-10) ; 5.2(1 \mathrm{H}, \mathrm{t}, J=1.5$ and $7 \mathrm{~Hz}, \mathrm{H}-15) ; 5.67(1 \mathrm{H}, \mathrm{d}, J=10 \mathrm{~Hz}, \mathrm{H}-20) ; 6.23(1 \mathrm{H}, \mathrm{d}, J$ $=1 \mathrm{~Hz}, \mathrm{H}-3$ '); $6.40(1 \mathrm{H}, \mathrm{s}, \mathrm{H}-8)$; and $6.65(1 \mathrm{H}, \mathrm{d}, J=10 \mathrm{~Hz}, \mathrm{H}-19)$.

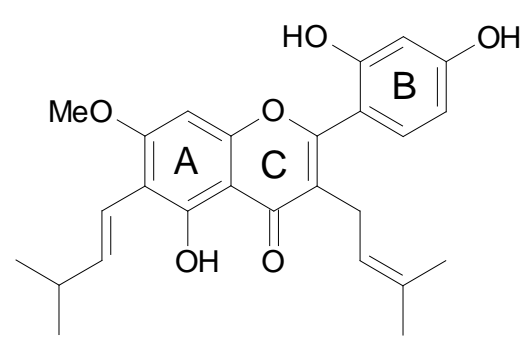

Artocarpin (1)

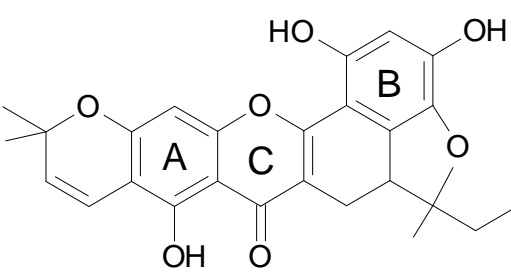

Artonin M (2)

Figure 1. Chemical structure of compounds $\mathbf{1}$ and $\mathbf{2}$

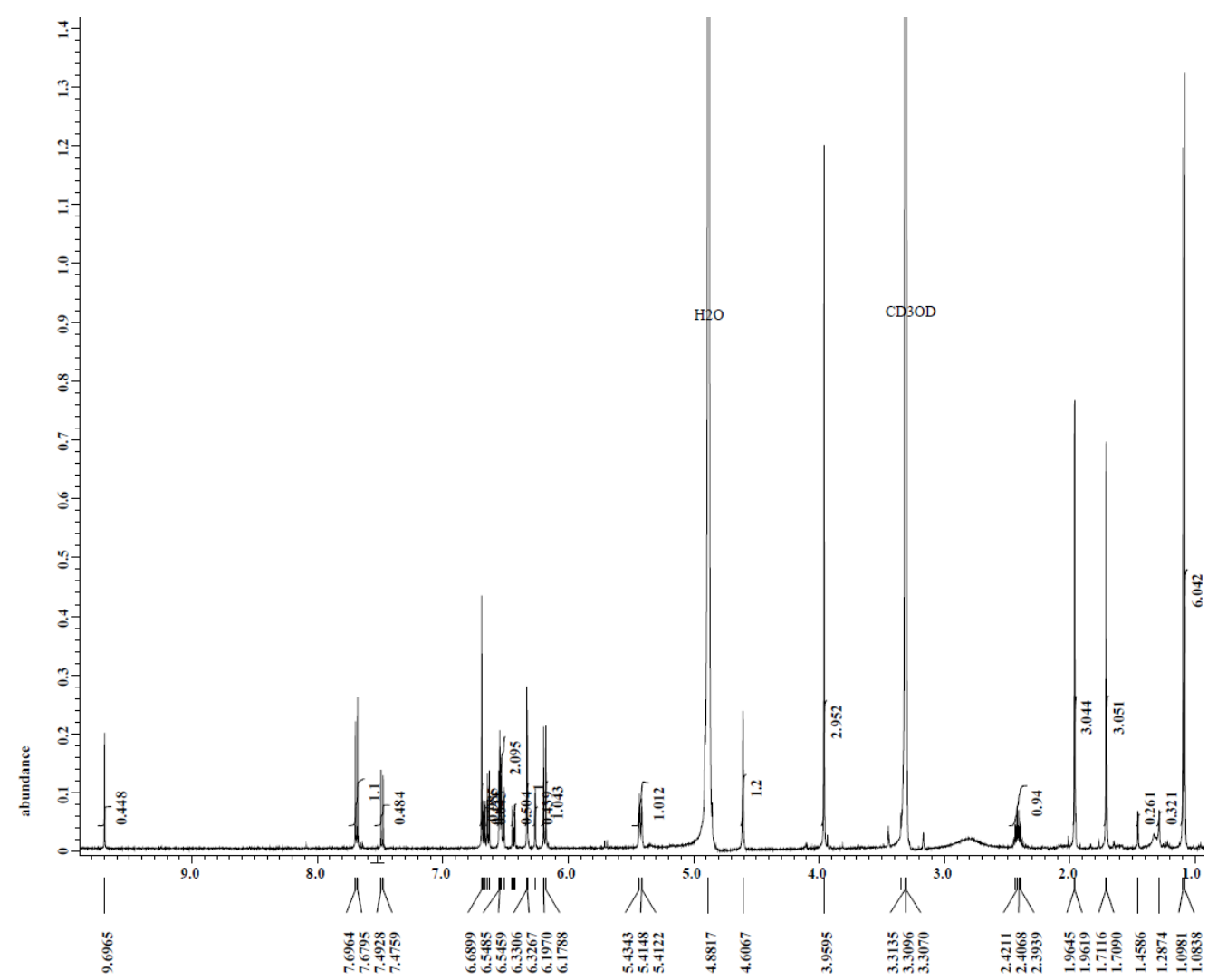

Figure 2. ${ }^{1} \mathrm{H}$ NMR spectrum of artocarpin (1) 


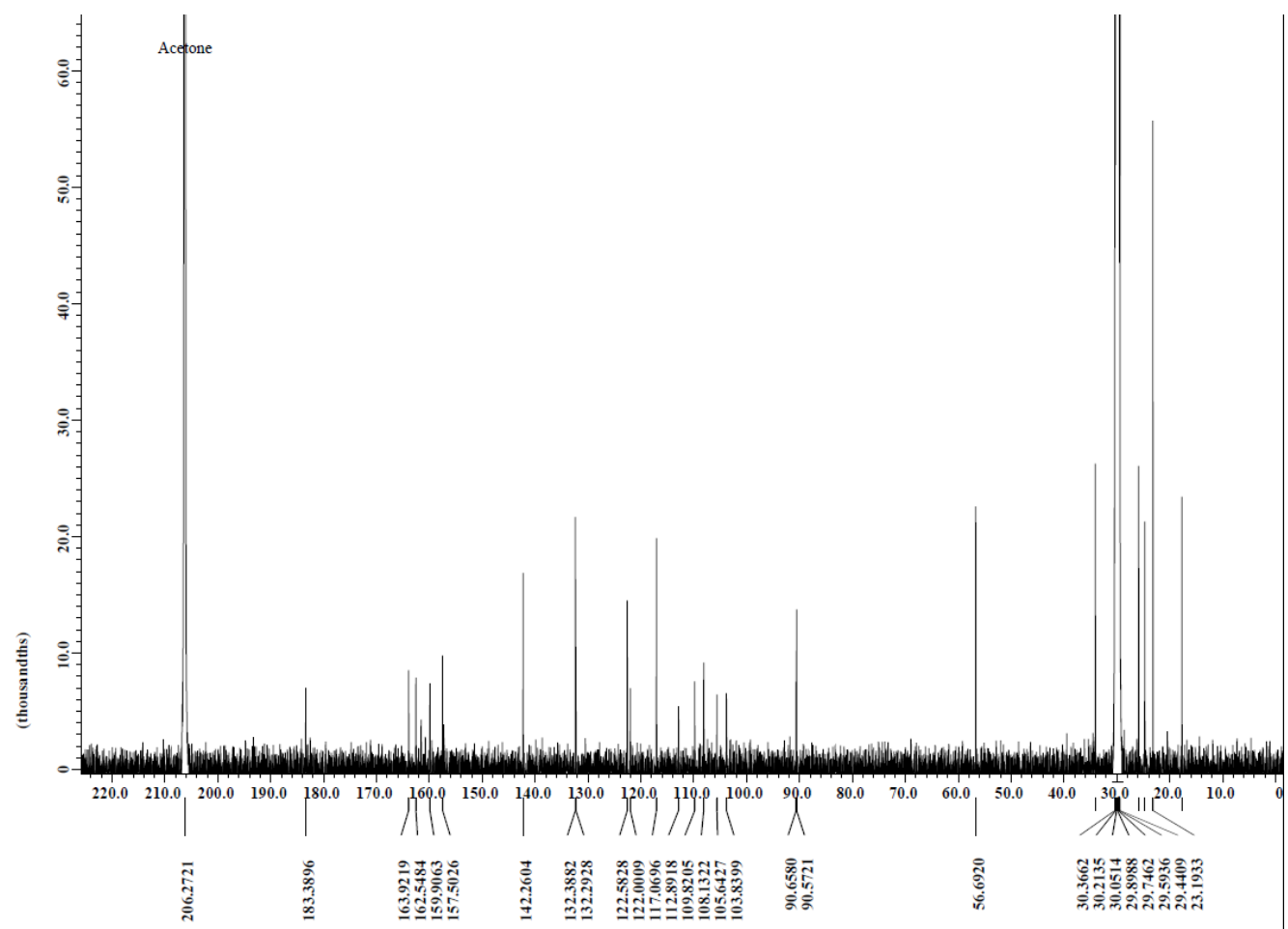

Figure 3. ${ }^{13} \mathrm{C}$ NMR spectrum of $\operatorname{artocarpin}(\mathbf{1})$

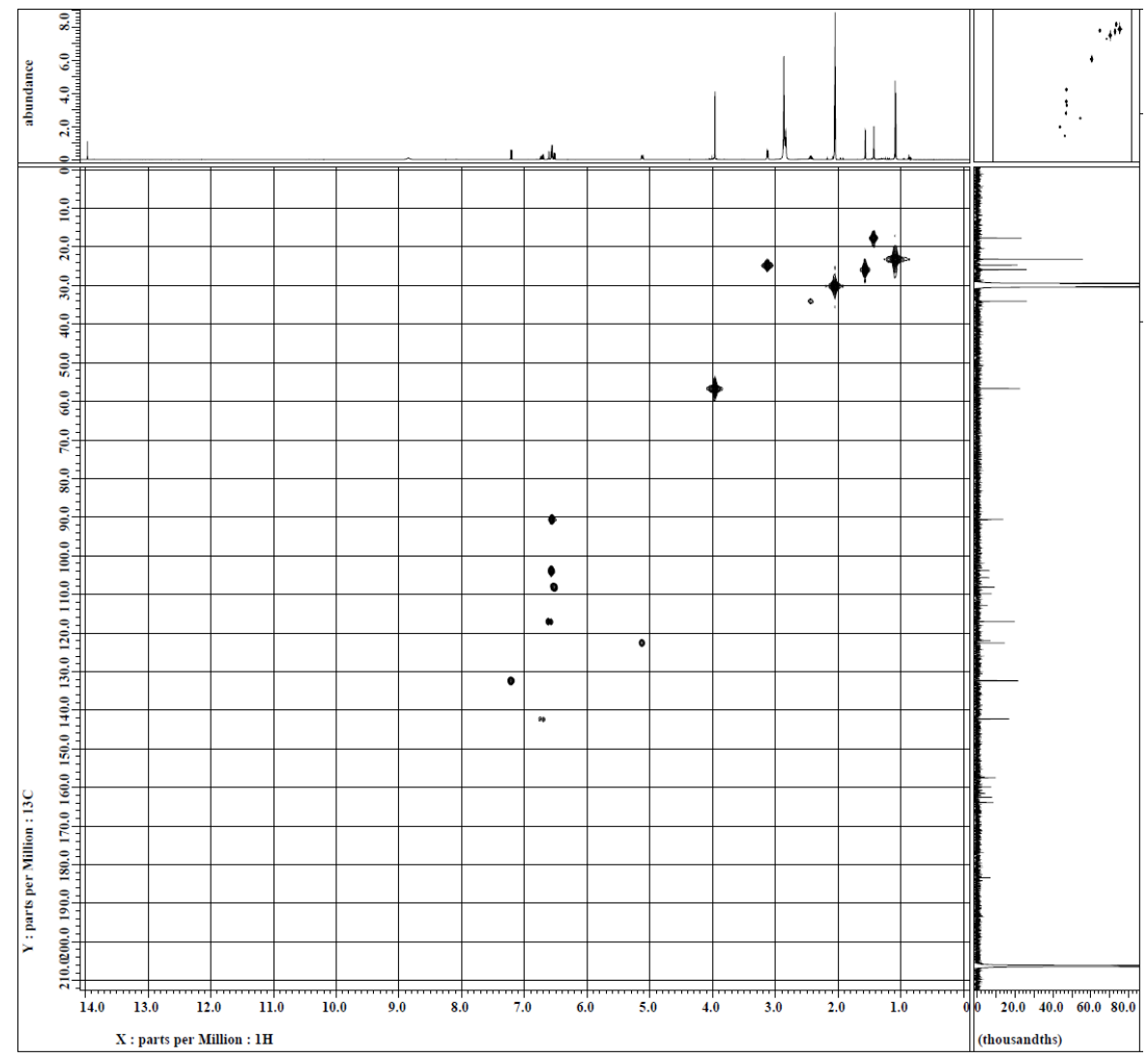

Figure 4. HMQC spectrum of 1 


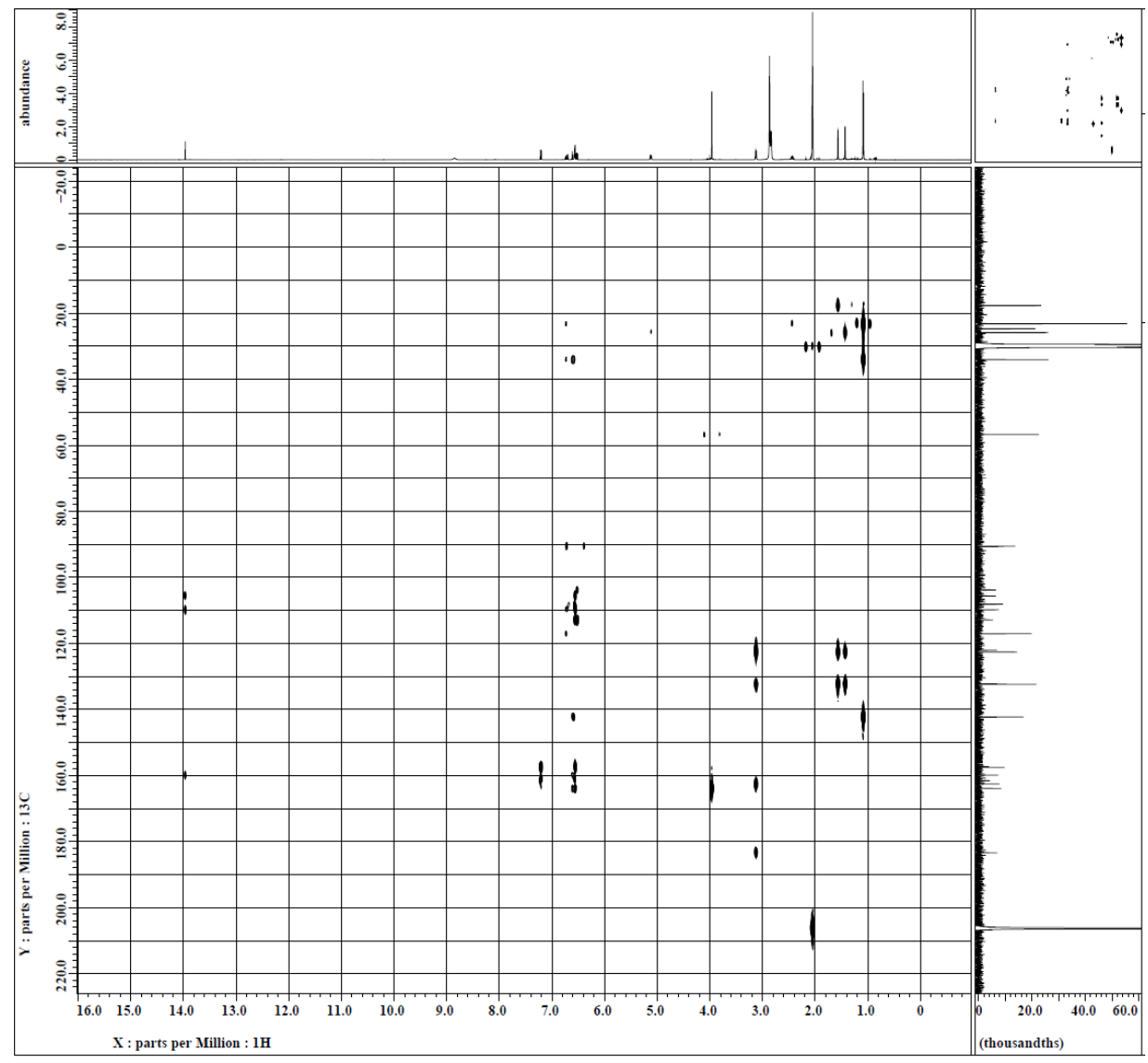

Figure 5. The correlation HMBC spectrum of $\mathbf{1}$

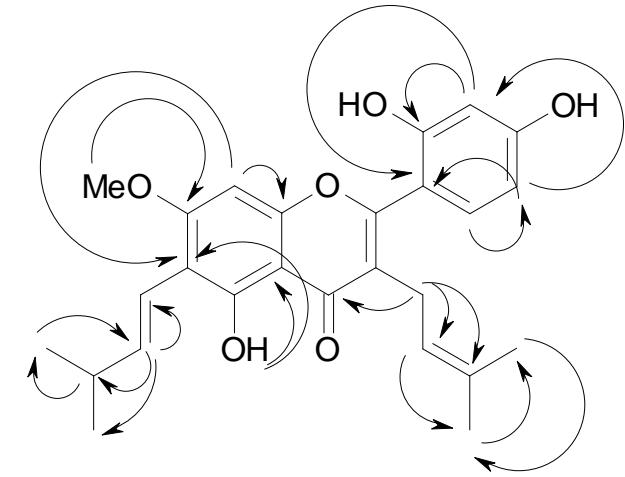

Figure 6. The important HMBC correlation of 1

\subsection{Antimalarial activity}

The in vitro antimalarial assay was performed following the procedures available in the literature and have been used previously in some of our publications [8-10]. However, the in vivo antimalarial test was carried out based on the procedure used published methods available in the literatures [11] and have also been used in our previous work [4].

\section{Results and discussions}

\subsection{In vivo antimalarial test of artocarpin (1)}

The growth of Plasmodium was inhibited upon administering the compound 1, where the higher dosage of compound 1 was used, in addition to the smaller parasitemia average and the higher percentage inhibition average. The dosage that resulted in the highest inhibition of Plasmodium was $100 \mathrm{mg} / \mathrm{kgBW}$, where it resulted in inhibition of $73.66 \pm 0.12 \%$. In the smallest dosage used, the inhibition of Plasmodium was still observed, although it was very low, with a percentage of $12.60 \pm$ 
$0.31 \%$. The probit calculation resulted the effective dose $50\left(\mathrm{ED}_{50}\right)$ of $34.88 \mathrm{mg} / \mathrm{kgBW}$ (Table 1). The parasitemia level and inhibition percentage of artocarpin is in Figure 7. According to Munoz et al. [12], the in vivo antimalarial activity was categorized as follows: $\mathrm{ED}_{50} \leq 100 \mathrm{mg} / \mathrm{kgBW} / \mathrm{day}$ is categorized as excellent, $\mathrm{ED}_{50} \quad 101-250 \mathrm{mg} / \mathrm{kgBW} /$ day categorized as good, $\mathrm{ED}_{50}$ 251-500 $\mathrm{mg} / \mathrm{kgBW} /$ day as medium, and $\mathrm{ED}_{50}>500 \mathrm{mg} / \mathrm{kgBW} /$ day as inactive. Based on these criteria, compound $\mathbf{1}$ is categorized as excellent drug; therefore, it will be excellent to be developed as an antimalarial drug in the near future.

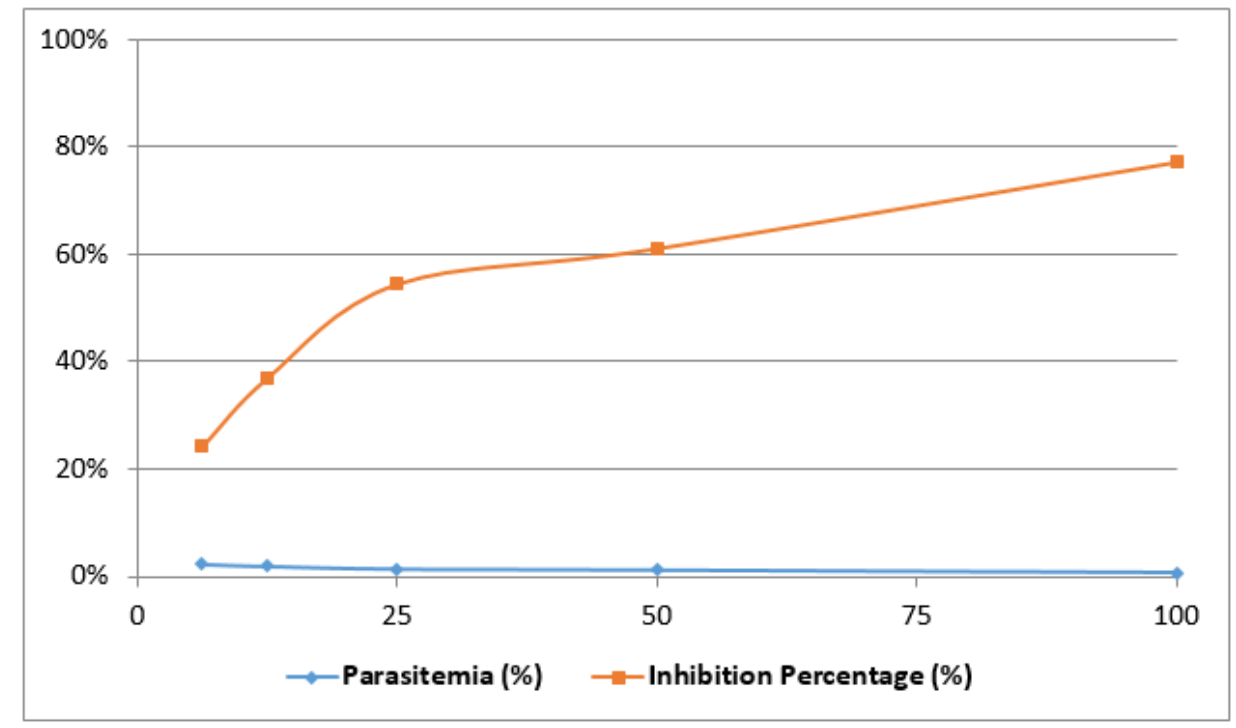

Figure 7. The parasitemia level and inhibition percentage of isolated artocarpin (1)

Table 1. Parasitemia value, inhibition percentage, $\mathrm{ED}_{50}, \mathrm{ED}_{90}$ and ED99 of isolated artocarpin (1)

\begin{tabular}{cccccc}
\hline $\begin{array}{c}\text { Dosage } \\
(\mathbf{m g} /\end{array}$ & $\begin{array}{c}\text { Parasitemia } \\
\mathbf{K} \%)\end{array}$ & $\begin{array}{c}\text { Inhibition } \\
\text { Percentage }(\%)\end{array}$ & $\begin{array}{c}\text { ED50 } \\
(\mathbf{m g} / \\
\mathbf{K g B W})\end{array}$ & $\begin{array}{c}\text { ED90 } \\
(\mathbf{m g} / \\
\mathbf{K g B W})\end{array}$ & $\begin{array}{c}\text { ED99 }(\mathbf{m g} / \\
\mathbf{K g B W})\end{array}$ \\
\hline 100.00 & $0.69 \%$ & $73.66 \%$ & & & \\
50.00 & $1.18 \%$ & $55.14 \%$ & & & \\
25.00 & $1.38 \%$ & $47.49 \%$ & 34.88 & 286.15 & \\
12.50 & $1.91 \%$ & $27.28 \%$ & & & \\
6.25 & $2.29 \%$ & $12.64 \%$ & & & \\
\hline
\end{tabular}

In the in vivo antimalarial activity test, some factors that demonstrate an effect on the result of the test exist. The individual factor of mice really affects the growth of $P$. Berghei, which also gives the varied picture of parasitemia. This condition normally affects the growth of $P$. berghe $i$ in the body of mice. The factor of Plasmodium also affects the number of parasetemia that occur in the mice. The host factor influencing the mice is the body resistance to eliminate Plasmodium from each mouse, while the factor of $P$. berghei that does not sincronize in the mice and is normally only $10 \%$ of $P$. berghei that was innoculated and can grow [13].

The presence of schizogony erythrocytic cycle on $P$. berghei inside the visceral organ, making the ring stage and trophozoit, are mostly taken as innoculum. The character of $P$. berghei also affects the 
speed of its growth inside the host [14]. Thus, these conditions perhaps is the cause of the parasitemia value being relatively low. The parasitemia negative control was only $2.63 \pm 0.01 \%$.

The mechanism of the compound tested as antimalarial was perhaps by inhibition mechanism of the heme polymerization. It has been found that the terpenoid compound will bind to a heme electronic system, and the hydroxyl group will be bound to heme iron [15]. The other mechanism in killing Plasmodium is probably available but which mechanism used is not known exactly.

\subsection{In vitro antimalarial of Artonin M (2)}

The results of in vitro antimalaria of 2 showed that this compound exhibits very high activity against Plasmodium, giving an $\mathrm{IC}_{50}$ value of $0.3 \mu \mathrm{g} / \mathrm{mL}\left(5.976 \times 10^{-7} \mathrm{M}\right)$, and this is comparable with the control positive chloroquine with an $\mathrm{IC}_{50}$ value of $3 \times 10^{-7} \mathrm{M}$. This value is stronger than the antimalarial drug from the organotin (IV) compound, which has been reported lately $[9,10,16]$ and may be better than other synthetic compounds having antimalarial activity which have been reported by others [17-20]. The data of activity test can be seen in Figure 8 and Table 2, while the data for the chloroquine are in Figure 9.

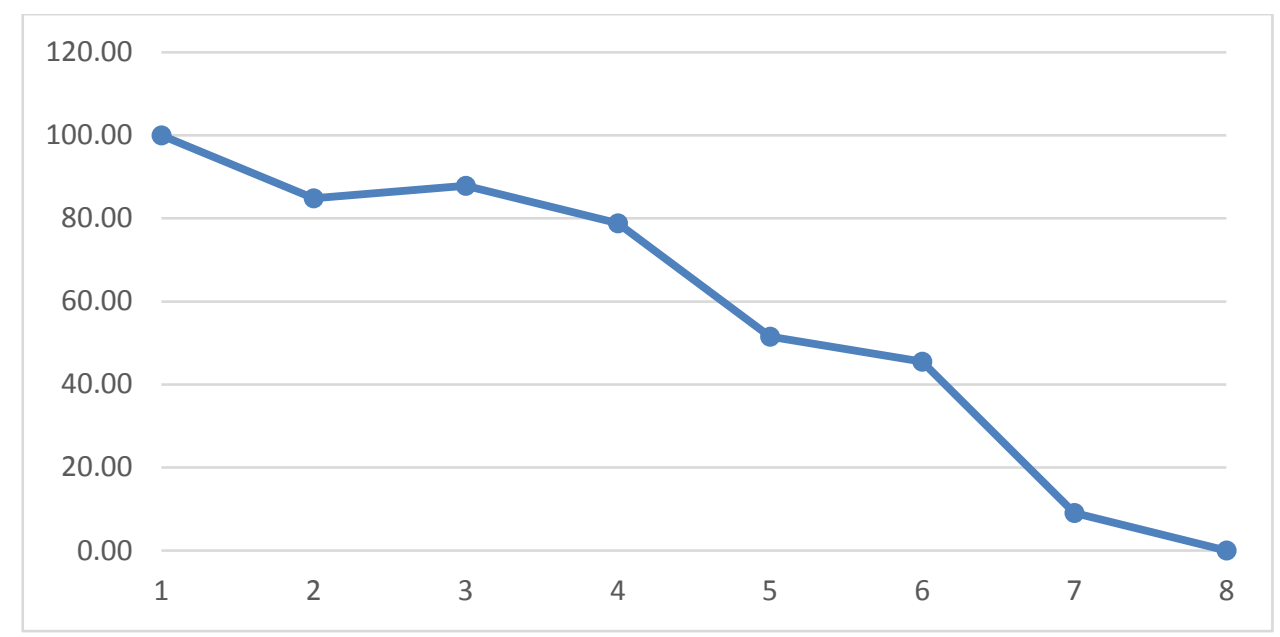

Figure 8. In vitro antimalarial assay of artonin $\mathrm{M}$

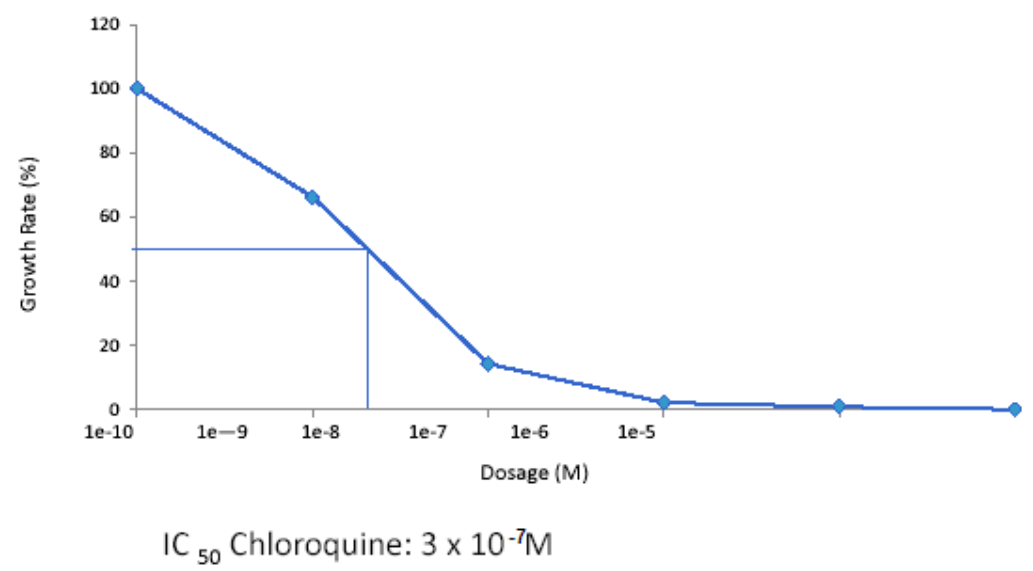

Figure 9. The result of in vitro antimalarial activity of chloroquine 
Table 2. In vitro antiplasmodial assay of artonin $\mathrm{M}$

\begin{tabular}{|c|c|c|c|c|c|c|c|}
\hline & & & & Plate 1 & Plate 2 & rate & Growth Rate $(\%)$ \\
\hline A & Artonin M & 1 & Untreated & 17 & 16 & 16.5 & 100.00 \\
\hline B & & 2 & $10^{-7}$ & 16 & 12 & 14 & 84.85 \\
\hline $\mathrm{C}$ & & 3 & $10^{-6}$ & 16 & 13 & 14.5 & 87.88 \\
\hline D & & 4 & $10^{-5}$ & 12 & 14 & 13 & 78.79 \\
\hline E & & 5 & $10^{-4}$ & 9 & 8 & 8.5 & 51.52 \\
\hline $\mathrm{F}$ & & 6 & $10^{-3}$ & 8 & 7 & 7.5 & 45.45 \\
\hline G & & 7 & $10^{-2}$ & 2 & 1 & 1.5 & 9.09 \\
\hline $\mathrm{H}$ & & 8 & $10^{-1}$ & 0 & 0 & 0 & 0.00 \\
\hline
\end{tabular}

Each molecule structure of $\mathbf{1}$ and $\mathbf{2}$ exhibits two hydroxyl groups at the meta position on B ring. The hydroxyl group at C-7 on A ring on these two compounds is not on a free state, and they exhibit one uncyclinazed isoprenyl group on the $\mathrm{C}$ ring at compound $\mathbf{1}$ and on furanodihydrobenzosanton at compound 2. The structure of these two compounds is similar for the position of two hydroxyl groups on $\mathrm{B}$ ring and the presence of prenyl or geranyl on $\mathrm{C}$ ring, thus making these compounds as active as antimalaria.

\section{Conclusions}

The result of in vivo antimalarial assay of artocarpin $\mathrm{ED}_{50}$ value obtained was $34.88 \mathrm{mg} / \mathrm{kgBW}$. This value indicated that artocarpin demonstrates very strong antiplasmodial activity. The result of in vitro antimalarial activity of artonin $\mathrm{M}$ resulted in strong activity with an $\mathrm{IC}_{50}$ value of $0.3 \mu \mathrm{g} / \mathrm{mL}$. This $\mathrm{IC}_{50}$ value also is an indication that artonin $\mathrm{M}$ has the potential to be developed as an antimalarial drug. The in vivo antimalarial of artocarpin and in vitro antimalarial of artonin $\mathrm{M}$ from Artocarpus plant are the first report of antimalarial activity assay. Based on the result reported here, the conclusion exists that A. altilis and A. kemando plants are one of the main sources to obtain the potential compound as antimalarial, which will be very useful for the replacement of some comercial drugs available in the market and caused the antimalarial resistency.

Acknowledgments: This work was funded by the Rector of University of Lampung and Research Institute and Community Service in the form of Professor Research grant scheme of Universitas Lampung with contract number of 2839 / UN26.21 / PN / 2019, July 5, 2019. The authors would like to thank Enago (www.enago.com) for the English language proofread and review.

\section{References}

1. BOONPHONG, S., BARAMEE, A, KITTAKOOP, P., PUANGSOMBAT, P. Antitubercular and Antiplasmodial prenylated flavones from the roots of Artocarpus altilis, Chiang Mai J. Sci., 34(3), 2007, 339-344.

2. WIDYAWARUYANTI, A., SUBEHAN, KALAUNI. S.K., AWALE, S., NINDATU, M., ZAINI, N.C., SYAFRUDDIN, D., ASIH, P.B.S., TEZUKA, Y., KADOTA, S. New prenylated flavones from Artocarpus champeden, and their antimalarial activity in vitro, J. Nat. Med., 61, 2007, 410-413.

3. MUSTAPHA, I., HAKIM, E.H., JULIAWATY, L.D., SYAH, Y.M., ACHMAD, S.A. Prenylated flavones from some Indonesian Artocarpus and their antimalarial properties, Med. Plants, 2(2), 2010, 145-148.

4. SUHARTATI, T., YANDRI, SUWANDI, J.F., HADI, S. In vitro and in vivo Antiplasmodial Activity of Oxyresveratrol and Artonin E Isolated from Two Artocarpus Plants in Indonesia, Orient. J. Chem., 26(3), 2010, 825-830.

5. EE, G.C.L., TEO, S.H., RAHMANI, M., LIM, C.K., LIM Y.M., GO, R. Artomandin, a new xanthone from Artocarpus kemando (Moraceae), Nat. Prod. Res., 25(10), 2011, 995-1003. 
6. SEO, E.K., LEE, D., SHIN, Y.G., CHAI, H.B., NAVARRO, H.A., KARDONO, L.B., RAHMAN, I., CORDELL, G.A., FARNSWORTH, N.R., PEZZUTO, J.M., KINGHORN, A.D., WANI, M.C., WALL, M.E. Bioactive prenylated flavonoids from the stem bark of Artocarpus kemando, Arch. Pharm. Res., 26, 2003, 124-127.

7. JAGTAP, U.B., BAPAT, V.A. Artocarpus: A review of its traditional uses, phytochemistry and pharmacology, J. Ethnopharmacol., 129(2), 2010, 142-166.

8. PETERS, W., PORTUS, J.H., ROBINSON, B.L. The chemotherapy of rodent malaria. XXII. The value of drug-resistant strains of P. berghei in screening for blood schizonticidal activity, Ann. Trop. Med. Parasit., 69(2), 1975, 155-171.

9. HADI, S., NOVIANY, QUDUS, H.I., WATTANA-AMORN, P. The Potency Study of Organotin (IV) 3-Nitrobenzoate Compounds as Antimalarial Agents. J. Phys.: Conf. Ser., 1338, 2019, 012012.

10. HADI, S., FENSKA, M.D., WIJAYA, R.A., NOVIANY, SUHARTATI, S. Antimalarial Activity of Some Organotin(IV) Chlorobenzoate Compounds against Plasmodium falciparum. Mediterr. J. Chem., 10(3), 2020, 213-219.

11. AJAIYEOBA, E., FALADE, M., OGBOLE, O., OKPAKO, L., AKINBOYE, D. In vivo Antimalarial and Cytotoxic Properties of Annona senegalensis Extract, Afr. J. Tradit. Complem., 3(1), 2006, 137-141.

12. MUNOZ, V., SAUVAIN, M., BOURDY, G., CALlAPA, J., BERGERON, S., ROJAS, I., BRAVO, J.A., BALDERRAMA, L., ORTIZ, B., GIMENEZ, A., DEHARO, E. A Search for Natural Bioavtive Compounds in Bolivia Through a Multidisciplinary Approach Part I. Evaluation of the Antimalarial Activity of Plants used by the Chocobo Indians, J. Ethnopharmacol., 69(2), 2000, 127137.

13. JANSE, C., WATERS, A. The Plasmodium berghei: Model of Malaria. 2006. Available from : http://www.lumc.nl/1040/research/ malaria/model.html, [Verified 28 February 2020].

14. FREMOUNT, H.N., MILLER, L,H. Deep Vascular Schizogony in Plasmodium Fragile: Organ Distribution and Ultrastructure of Erythrocytes Adherent to Vascular Endothelium, Am. J. Trop. Med. Hyg., 24(1), 1975, 1-8.

15. SULLIVAN JR., D.J., MATILE, H., RIDLEY, R.G., GOLDBERG, D.E. A Common Mechanism for Blockade of Heme Polymerization by Antimalarial Quinolines, J. Biol. Chem., 273(47), 1998, 31103-31107.

16. HADI, S., NOVIANY, RILYANTI M. In Vitro Antimalarial Activity of Some Organotin(IV) 2Nitrobenzoate Compounds Against Plasmodium falciparum. Maced. J. Chem. Chem. Eng., 37(2), 2018, 185-191.

17. BAHRIN , L.G., HOPF, H., JONES, P.G., EARAR, K., BIRSA, L.M. Synthesis and Structural Characterization of a New Iodine-containing Phenacyl N,N-Diethylamino Carbodithioate Rev. Chim., 67(1), 2016, 61-63.

18. CAlineSCU, M., STOICA, C., NITA-LAZAR, M., Complex Compounds of Sm(III) with Chlorhexidine Synthesis, characterization, luminescent properties and antibacterial activity, Rev. Chim., 70(1), 2019, 6-12.

19. TATARINGA, G., SATHYAMURTHY, B., SANDU, I., ZBANCIOC, A.M., In silico Docking Study of Some Coumarin Derivatives as Potential Inhibitors on Different Dengue Viral Proteins, Rev. Chim., 70(9), 2019, 3387-3391.

20. FARCAS, C.G., MOACA, E.A., DRAGOI, R., VADUVA, D.B., MARCOVICI, I., MIHALI, C.V., LOGHIN, F., Preliminary Results of Betulinic Acid-Loaded Magnetoliposomes - a Potential Approach to Increase Therapeutic Efficacy in Melanoma, Rev. Chim., 70(9), 2019, 3372-3377

Manuscript received: 13.03 .2020 